\title{
SISTEM MASYARAKAT DAN ORGANISASI SUKU DAYAK NGAJU (STUDI KASUS DI DESA MANDOMAI KALIMANTAN TENGAH)
}

\author{
Rizka Bella, Stevany, Ahmad Ilham Gujali, Ratna Sari Dewi, Eddy Lion, \& Maryam \\ Mustika \\ Universitas Palangka Raya \\ Rizkabella246@gmail.com
}

\begin{abstract}
Abstrak
Penelitian ini bertujuan untuk mengetahui sistem masyarakat dan organisasi suku Dayak Ngaju didesa mandomai Kalimantan Tengah. Metode yang digunakan adalah kualitatif deskriptif. Sumber data yaitu sumber data primer dan sumber data sekunder. Prosedur pengumpulan data menggunakan observasi, wawancara dan dokumentasi sedangkan analisis data meliputi data collection, data reduction, data display, conclusion drawing. Hasil penelitian ini menunjukkan bahwa sistem masyarakat dan organisasi suku Dayak Ngaju di desa mandomai kalimantan tengah. Pada awalnya adalah salah satu daerah sebagai tempat menetap bagi masyarakat desa sebelum adanya pemekaran wilayah.sehingga sistem masyarakatnya termasuk sistem bilateral yaitu menarik garis keturunan melalui pihak ayah dan ibu. Kemudian untuk memenuhi kebutuhan dulu hingga sekarang sebagai petani namun seiringnya perkembangan zaman Sebagian masyarakat mandomai banyak keluar daerah untuk mencari pekerjaan.sehingga organisasi sosialnya saat ini masih banyak selaras dengan perubahan zaman. dengan adanya organisasi sosial sangat bermanfaat bagi masyarakat Dayak di mandomai yaitu salah satunya adalah membantu dalam bidang pertanahan, Kesehatan dan lain sebagainya.
\end{abstract}

Kata Kunci : suku dayak, sistem masyarakat, organisasi sosial

\begin{abstract}
The study aims to identify the social and tribal systems of the dayak ngaju in the village of mandomai central kalimantan. The method used is a descriptive qualitative. The data source is the primary and secondary data source. Data collection procedures include observation, interviews and documentation while data analysis includes data collection, data reduction, display data, demographic results. The results of the study show that the indigenous dayak ngaju community and tribal organization in the village of mandomai central kalimantan. Initially it was one of the areas to settle for village people before the region was exposed. So their social system is bilateral, which is to draw the line through the father and mother. Then, to meet the needs of farmers, and to this day as farmers, most of the population has been mandated to go out of the country in search of work. So his social organization today is still much in keeping with the changing times. With social organizations helping the dayak people in mandomai, one of which is to help with land, health, and so on.
\end{abstract}

Keywords : Dayak people, social systems, social organizations.

\section{PENDAHULUAN}

Suku Dayak adalah nama yang diberi oleh penjajah kepada penghuni pedalaman pulau Borneo yang mendiami Pulau Kalimantan (Brunei, Malaysia), yang terdiri dari Sabah dan Sarawak, serta Indonesia yang terdiri dari Kalimantan Barat, Kalimantan Timur, Kalimantan Tengah, Kalimantan Utara, dan Kalimantan Selatan). Kalimantan tengah memiliki tiga suku besar, yaitu banjar, jawa dan ngaju
(Pitoyo dan Triwahyudi, 2017:71). Ada 5 suku atau 7 suku asli Kalimantan yaitu Melayu, Dayak, Banjar, Kutai, Paser, Berau dan Tidung.

Menurut sensus Badan Pusat Statistik Republik Indonesia tahun 2010, suku bangsa yang terdapat di Kalimantan Indonesia dikelompokkan menjadi 4 suku pokok yaitu suku Banjar, suku Dayak Indonesia (268 sub etnik/sub suku), Suku Melayu, dan suku asal Kalimantan lainnya 
(non Dayak, non Melayu dan non Banjar). Dahulu, budaya masyarakat Dayak adalah budaya maritim atau bahari. Hampir semua nama sebutan orang Dayak mempunyai arti sebagai sesuatu yang berhubungan dengan "perhuluan" atau sungai, terutama pada nama-nama rumpun dan nama kekeluargaannya. Ada yang membagi orang Dayak dalam enam rumpun yakni rumpun Klemantan alias Kalimantan, rumpun Iban, rumpun Apokayan yaitu Dayak Kayan, Kenyah dan Bahau, rumpun Murut, rumpun Ot Danum-Ngaju dan rumpun Punan. Namun secara ilmiah, para linguis melihat 5 kelompok bahasa yang dituturkan di pulau Kalimantan dan masing-masing memiliki kerabat di luar pulau Kalimantan.

Alasan kami mengambil penelitian pada suku dayak ngaju di desa mandomai karena suku Dayak memiliki keunikan tersendiri meskipun sudah banyak yang mengangkat tentang suku Dayak ngaju akan tetapi disini kami akan kembali memperbaharui informasi tentang suku Dayak ngaju sekarang. Suku dayak ngaju merupakan sub etnis dayak terbesar di Kalimantan tengah yang persebarannya cukup luas dan utamanya terkonsentrasi di daerah Kota Palangka Raya, Kabupaten Pulang Pisau, Kabupaten Gunung Mas, Kabupaten Kapuas dan di kabupaten lainnya di seluruh wilayah kalimantan tengah dapat ditemui suku Ngaju.

Berdasarkan kesepakatan dan keputusan bersama kami akan melaksanakan penelitian kami yang Insyaallah atas izin Tuhan dan dosen pembimbing sekalian kami akan mengambil daerah penelitian di desa mandomai yaitu tepatnya di kabupaten Kapuas kecamatan Kapuas barat. Kecamatan Kapuas Barat (Mandomai) terletak di daerah pesisir bantaran sungai Kapuas, di masa lalu Mandomai ini bernama Tacang Tanggoehan sekitar abad ke-17, pada saat perang Kasintu pecah, orang-orang yang berada di daerah Tacang Tanggoehan pun mengungsi ke daerah Pulau Petak, sekitar tahun 1803-an mereka kembali lagi ke daerah Tacang Tanggoehan dan membangun dua buah rumah betang yang disebut "huma gantung"(rumah tinggi) atau "huma hai"(rumah besar) yang terletak di sebelah hulu sungai Mandomai. (norliansyah, sejarah singkat mandomai, 2010). Hal inilah yang membuat kami sangat tertarik melakukan penelitian ditempat ini karena keingin tahuan kami akan sistem masyarakat dan bagaimana pola kehidupan masyarakat di desa mandomai tersebut.

Sesuai dengan judul yang akan kami angkat yaitu "sistem masyarakat dan organisasi suku Dayak ngaju di Desa Mandomai Kalimantan Tengah" kami akan mendeskripsikan segala hal yang ada di desa tersebut agar masyarakat Indonesia lebih mengenal luas lagi apa itu suku Dayak khususnya suku Dayak ngaju dan untuk menambah wawasan serta warisan tentang edukasi kebudayaan Indonesia.

Sistem kekerabatan yang dianut oleh suku bangsa Dayak adalah bilateral, yaitu menarik garis keturunan melalui pihak ayah dan ibu. Dengan demikian sistem pewarisanpun tidak membedakan anak laki-laki dan anak perempuan. Bentuk kehidupan keluarga terdiri atas dua jenis yaitu keluarga batih (nuclear family) dan keluarga luas (extended family). Pada kedua bentuk keluarga ini biasanya terdapat wali/asbah yang berfungsi untuk mewakili keluarga dalam berbagai kegiatan sosial dan politik di lingkungan dan di luar keluarga. Yang menjadi wali/asbah dalam keluarga batih adalah anak laki-laki tertua, sedangkan dalam keluarga luas yang berhak menjadi wali/asbah adalah saudara laki-laki ibu dan saudara laki-laki ayah. Dalam sistem keagamaan, agama asli suku dayak yang ada dikalimantan adalah kaharingan, yang merupakan agama asli yang lahir dari budaya setempat sebelum 
bangsa indonesia belum mengenal agama pertamanya yakni hindu (Darmadi, 2016 : 326).

Pada umumnya sistem pencaharian yang paling utama adalah ekonomi subsistem dalam bentuk perdangan tidak menetap (berpindah-pindah), berburu, menangkap ikan secara tradisional, serta meramu hasil hutan yang ada di sekitar mereka (Dewantara \& Nurgiansah, 2021). Disamping berladang mereka juga menyerap karet dan memotong rotan. Berburu yang umum adalah dengan membawa beberapa ekor anjing ke dalam hutan dan membawa tombak, disamoing itu pula bisa dilakukan dengan memasang perangkap. Adat istiadat dan hukum adat adalah nilai-nilai normatif yang mengatur tata kehidupan orang dayak sehingga mereka disebut dengan belom bahadat atau hidup beradat. Kemudian sistem kesenian dalam kalangan suku dayak ngaju sangat terbatas pada kesenian tari yang bermakna sebagai tarian pergaulan dan untuk menyambut tamu. kemudian untuk sistem teknologi suku dayak relatif sederhana, karena peralatan yang mereka gunakan umumnya berhubungan dengan kegiatan-kegiatan pertanian, berburu, menangkap ikan, membangun rumah panggung. Perlatan seperti pisau dan beliung merupakan perlatan unutk berladang, sedangkan tombak dan pisau adalah senjata unutk berburu secara langsung (Sari Eviyanti, 2010: 7).

Digambarkan bahwa pola hidup dan kebudayaan orang dayak ngaju telah mengalami perubahaan akibat dari adanya percampuran kebudayaan dengan masyrakat dan kebudayaan suku bangsa lain di indonesia dan juga adanya pengaruh dari kebudayaan asing serta penetrasi kebudayaan nasional indonesia (Nurgiansah, 2021c). Di samping itu dalam buku ini dijelaskan dan dideskripsikan bagaimana pola strategis budaya yang dianut oleh orang dayak ngaju dalam melaksanakan kehidupan yang senantiasa mengalami perubahan, khususnya dalam organisasi sosial untuk mengatur pola kehidupan masyarakat dayak ngaju secara keseluruhan di daerah satu desa sigi dan juga mengetahui hubungan - hubungan social yang ada dalam masyarakat desa sigi. Sehingga organisasi social yang ada di sebuah desa sigi berperan sebagai institusi masyarakat yang dominan dalam kehidupan manusia dan juga sebagai perkumpulan social yang di bentuk oleh masyarakat dayak ngaju agar berfungsi sebagai sarana partisipasi masyarakat dalam pembangunan desa karena membentuk organisasi social berperan penting untuk mencapai tujuan - tujuan sebuah desa. (Kumpiadi Widen, Poltak Johansen, 2009 : 22).

Serta dalam sebuah desa memiliki sebuah kebudayaan sehingga harus mengetahui kebudayaan - kebudayaan yang di lestarikan masyarakat dayak ngaju di desa sigi karena dalam melaksanakan sebuah kebudayaan selalu memiliki rasa kemasyarakatan sehingga saling bergotong royong menunjuk nilainilai dan cara hidup yang dimiliki Bersama. Kebudayaan pun memiliki suatu masyarakat di dalamnya terdapat system nilai budaya yang di anggap bersifat positif sehingga memungkinkan masyarakat tersebut berkembang. Masyarakat menunjuk kepada kumpulan manusia yang hidup Bersama di suatu desa yang telah cukup lama dan mempunyai aturan-aturan yang mengatur mereka untuk menuju ke tujuan yang sama. Manusia pada dasarnya hidup sebagai makhluk budaya yang memiliki akal, budi, dan daya untuk dapat membuahkan suatu gagasan dan hasil karya yang berupa seni, moral, hukum dan kepercayaan yang terus di lakukan dan pada akhirnya membentuk suatu kebiasaan atau adat istiadat yang di anut sebuah desa kemudian di akamulasikan dan di 
transmisikan secara sosial atau kemasyarakatan (Nurgiansah, 2020).

Kebudayaan berarti buah budi manusia adalah hasil perjuangan manusia terhadap dua pengaruh kuat yakni zaman dan alam yang merupakan bukti kejayaan hidup masyarakat untuk mengatasi berbagai rintangan dan kesukaran di dalam hidup dan penghidupannya guna mencapai keselamatan dan kebahagiaan yang pada akhirnya bersifat tertib dan damai sehingga cara khas manusia beradaptasi dengan lingkungannya yakni cara manusia membangun alam guna memenuhi keinginan-keinginan serta tujuan hidupnya. Fungsi kebudayaan agar mendasari, mendukung dan mengisi masyarakat dengan nilai-nilai hidup untuk dapat bertahan menggerakan serta membawa masyarakat kepada taraf hidup tertentu yaitu hidup lebih baik, lebih manusiawi dan berprikemanusiaan (Nurgiansah, 2021b).

Sedangkan organisasi sosial pada umumnya berpola kerja terstruktur mempunyai tujuan organisasi di didirikan bukan untuk siapa-siapa dan bukan tanpa tujuan. Namun organisasi didirikan karena manusia sebagai makhluk social sukar mencapai tujuan individualnya jika segala sesuatu harus di kerjakan sendirian. Tetapi lebih efisien juga jika segala sesuatu di kerjakan Bersama-sama kalau dalam kemasyarakatan. Organisasi social misalnya mengidenfikasi system-system desa, kepala adat sebagai segi-segi organisasi social sebab bahwa desa adalah unit dasar organisasi social dalam kemasyarakatan. Kepala adat bertanggung jawab juga atas kesejahteraan dan kemakmuran masyarakatnya (Nurgiansah, 2021a).

Kepala adat mempunyai kekuasaan dalam membentuk sebuah pelaksanaan kebudayaan mewakili masyarakatnya dalam segala hal berurusan dengan desa maupun antar desa. Kepala adat yang memimpin desa di harapkan menjalankan peradilan dan mengawasi benda-benda keramat dan jalannya upacara-upacara keagamaan. Jabatan kepala adat di peroleh melalui pemilihan. Kepala adat memiliki kehormatan dan kewibawaan yang cukup besar khususnya di kalangan masyarakat desa di mana dia bertanggung jawab mengawasi upacara-upacara adat yang ada di masyarakat. Peran kepala adat juga bertindak sebagai hakim dengan kekuasaan untuk menetapkan denda bagi yang melanggar aturan adat yang ada di desa tersebut. Kepala adat mengadili pelanggaran-pelanggaran dan menajatuhkan berupa benda-benda.

Modernisasi seringkali di anggap sebagai anugrah tapi juga di anggap sebagai kutukan, setidaknya paradoks inilah yang di alami masyarakat suku, bersandar pada tesis bahwa hamper seluruh kehidupan mereka bersifat dekaden, pasif dan tradisional maka pengembang-pengembang modernisasi merasa perlu memodernisasikan dan mencerahkan masyarakat suku. Lewat suatu proses yang tak jarang sangat keras dalam bingkai persekongkolan pembangunan masyarakat dan agama resmi.

Dalam buku Tjilik Riwut yang berjudul Kalimantan Membangun, menjelaskan bahwa suku Dayak di Kalimantan dapat digolongkan menjadi tujuh kelompok besar, sebagai berikut: Dayak Iban; Ot' Danum; Punan; Apokayan; Ngaju; Klemantan dan Murut, kemudian terbagi menjadi 60 sub suku dan terbagi lagi menjadi 405 suku kecil. Biasanya penamaan sub suku yang paling kecil disesuaikan dengan nama anak sungai atau cabang sungai di mana mereka tinggal, misalnya: suku Bahau di sungai Bahau, Punan Tubu di sungai Tubu, Punan Boh di sungai Boh, suku Katingan di sungai Katingan, Punan Mentarang di sungai Mentarang, suku Bungan di sungai Long Bungan, dan lain sebagainya. 
Persebaran masyarakat Dayak terjadi sudah sangat lama, seperti cerita yang menyebar di internal masyarakat Kayan, Kalimantan barat, bahwa Suka Kayan pada mulanya tinggal di Apokayan, dan oleh karena itu mereka menamakan suku Apokayan, sedangkan mereka menamakan orang Ulu dan penyebutan "Dayak" untuk menamakan suku di luar mereka, seperti: Iban, Bidayuh, dan lain sebagainya. Menurut cerita yang berkembang dalam masyarakat bahwa suku Kayan merupakan kelompok besar dan mempunyai persenjataan lengkap, sehingga banyak suku Dayak lainnya seperti: suku Ot Danum, Penihing, Bukat, Punan, dan lain sebagainya, tergusur oleh suku Kayan, kemudian berpindah ke daerah-daerah yang lebih aman (Nurgiansah, 2021d).

Perpindahan tersebut dilakukan di berbagai daerah pedalaman hingga ke hulu sungai Mahakam dan beberapa aliran sungai Barito, Kahayan di Kalimantan Tengah. Kemiripan budaya dan bahasa antara suku Dayak yang tinggal di hulu sungai Mahakam dengan kelompok suku Dayak yang tinggal di hulu sungai Kapuas Kalimantan Barat menunjukan adanya hubungan dekat yang pernah terjadi pada masa lalu. Suku dayak adalah suku asli yang mendiami pulau kalimantan, secara umu penyebaran suku ini hampir merata di seluruh wilayah kalimantan tengah.(Riswanto Dody , 2017:217).

Dayak adalah sebuah nama dan sekaligus sebagai ciri identitas etnis bagi suku bangsa proto Melayu (Melayu Tua) yang diklaim sebagai penduduk pribumi pulau Kalimantan. Di Kalimantan Tengah konsep religi (kepercayaan) suku bangsa Dayak di kenal dengan nama Agama Kaharingan. Pada umumnya pola permukiman suku bangsa Dayak memanjang mengikuti alur sungai di mana mereka berada. Sumber penghidupan yang paling utama adalah ekonomi subsisten dalam bentuk perladangan tidak menetap (berpindah-pindah), berburu, menangkap ikan secara tradisional, serta meramu hasil hutan yang ada disekitar mereka.

Perladangan berpindah-pindah mereka lakukan sekali dalam setahun dengan cara slash and burn atau dengan cara tebas, tebang dan bakar lalu padi ditanam. Kondisi geografis di Kalimantan Tengah paling sedikit memiliki tiga ciri: yaitu daerah pesisir, daerah rawa-rawa, dan daerah perbukitan dan aliran sungai. Adat-istiadat adalah nilai-nilai normatif yang mengatur tata kehidupan orang Dayak sehingga mereka disebut dengan Belom Bahadat atau hidup beradat. Adat dibagi menjadi dua, yaitu adat yang mengatur tentang kehidupan(siklus kehidupan mulai di dalam perut, kelahiran hingga kematian, dan berbagai aktivitas dan interaksi sosial selama hidup di dunia), dan adat yang mengatur tentang upacara kematian.

Terminologi Dari perspektif ekologi bahasa, ternyata Bahasa Dayak Ngaju berperan penting sebagai media komunikasi dan interaksi budaya masyarakat. Beragam terminologi dalam bahasa Dayak Ngaju yang menjadi kekuatan dalam mewujudkan reformasi agraria, antara lain: Pertama, Hutan tidak dapat dipisahkan dari masyarakat Dayak Ngaju, tidak hanya sebagai tempat hidupnya tanaman dan binatang. Lebih dari itu, hutan adalah sumber kehidupan spritual masyarakat.

Kehidupan masyarakat Dayak Ngaju tidak dapat dilepaskan dari keberadaan hutan. Kedua, Nilai sosial dan kultural dalam budaya dan seremoni peribadatan Maniring Hinting dan kepercayaan terhadap Ranying Hatala memberi dampak magis dan psikologis bagi masyarakat untuk mengelola tanah dengan baik. Orang Dayak Ngaju meyakini jika tidak melaksanakan dan mematuhi hukum tanah, maka Ranying Hatalla akan marah 
dengan mengirimkan bencana alam, seperti banjir, tanah longsor, dan lain-lain.

$$
\text { Tanpa memandang sistem }
$$

kepercayaan terhadap Ranying Hatalla, faktor rusaknya lingkungan akibat dari melanggarnya hukum tanah Dayak Ngaju memang akan menimbulkan bencana alam terhadap lingkungan sekitar. Ketiga, Konsep konservasi dan perlindungan tanah suku Dayak Ngaju melalui penggunaan berbagai terminologi antara lain; Tajahan, yaitu lokasi tanah yang dikeramatkan oleh suku Dayak Ngaju dan umumnya berada di kawasan tanah hutan rimba belantara yang masih lebat. Kaleka, dipercaya oleh masyarakat sebagai peninggalan nenek moyang.

Tempat ini dilindungi secara turun temurun oleh keluarga karena potensinya sebagai lumbung pemberdayaan varietas unggul bibit tanaman. Sapan Pahewan, merupakan surga bagi binatang liar yang hidup di area hutan masyarakat. Tempat ini merupakan sumber mata air asin sebagai mineral bagi kehidupan binatang. Terakhir, Pukung Himba merupakan istilah yang digunakan masyarakat untuk wilayah cadangan dalam aktivitas mengelola tanah.

Tempat ini tidak dapat diperkenankan untuk pembukaan ladang baru bagi masyarakat, karena fungsinya sebagai persediaan sumber kehidupan masyarakat. Pemertahanan istilah-istilah tersebut menjadi faktor penting dalam pelestarian lingkungan dan pengelolaan tanah dengan baik. Jika masyarakat tidak lagi mengenal beragam terminologi yang memiliki pemaknaan yang mendalam tersebut, maka kerusakan alam dan eksploitasi tanah akan semakin masif. Karena hal tersebut dianggap sebagai kewajaran.

\section{METODE PENELITIAN}

Lokasi Penelitian dilakukan di Desa Mandomai, Kecamatan Kapuas Barat, Kabupaten Kapuas, Provinsi Kalimantan
Tengah. Peneliti memilih lokasi ini, karena di daerah ini terletak didaerah pesisir bantaran sungai kapuas, masyarakat desa mandomai mayoritas agama islam, terdiri dari berbagai macam etis dan mayoritas penduduk adalah etnis dayak. Mata pencarian sebagai petani dan memiliki sistem kemasyarakatkan Handep atau gotong royong yang memiliki nilai-nilai luhur, moral yang makna sabar, bijaksana, saling menolong. Lembaga-lembaga organisasi didesa mandomai dibentuk untuk kebutuhan masyarakat terlebih pada masyarakat sehingga lembaga ini dari keinginan-keinginan warga masyrakat itu sendiri. Pendekatan yang digunakan dalam penelitian ini adalah pendekatan kualitatif. Pendekatan kualitatif memiliki karakteristik alami (natural serfing) sebagai sumber data langsung. Analisis induktif dan makna-makna merupakan hal yang esensial (Meleong, 2013).

Objek dalam penelitian kualitatif adalah objek yang alamiah, atau natural setting, sehingga penelitian ini sering disebut penelitian naturalistic. Obyek yang alami adalah objek yang apa adanya, tidak dimanipulasi oleh peneliti sehingga kondisi pada saat peneliti memasuki objek, setelah berada di objek dan keluar dari objek relatif tidak berubah. Dalam penelitian kualitatif peneliti menjadi instrumen. Oleh karena itu dalam penelitian kualitatif instrumennya adalah orang atau Human instrument. Untuk menjadi instrumen peneliti harus memiliki bekal teori dan wawasan yang luas, sehingga mampu bertanya, menganalisis, memotret dan mengkontruksi objek yang diteliti menjadi jelas dan bermakana. Kriteria data dalam penelitian kualitatif adalah data yang pasti. Data yang pasti adalah data yang sebenarnya terjadi sebagaimana adanya, bukan data yang sekedar terlihat, terucap, tetapi data yang mengandung makna dibalik yang terlihat dan terucap tersebut. (Sugiyono, 2008). 
Dalam penelitian ini, data yang diperoleh berasal dari sumber data primer dan sumber data sekunder. Teknik analisis data yang digunakan dalam penelitian ini, Teknik analisis data yang akan digunakan dalam penelitian ini adalah teknik analisis data Model Miles dan Huberman. Pada teknik ini, pengumpulan data ditempatkan sebagai komponen yang merupakan bagian integral dari kegiatan analisis data.

\section{HASIL PENELITIAN DAN PEMBAHASAN Hasil Penelitian}

Temuan ini merupakan deskripsi dari data yang diperoleh dalam pengumpulan data dilapangan melalui observasi, wawancara dan dokumentasi. Selanjutnya dalam pemabahasan akan dilakukan analisis hasil penelitian mengenai sistem kemasyarakatan dan organisasi sosial masyarakat dayak ngaju di desa mandomai. Adapun yang menajdi fokus penelitian (1) bagaimana sistem kemasyarkatan suku dayak ngaju di desa mandomai, (2) Bagaimana struktur organisasi sosial di suku Dayak ngaju desa mandomai Kalimantan tengah, (3) Bagaimana dinamika perubahan struktur organisasi sosial suku Dayak ngaju didesa mandomai Kalimantan tengah.

\section{Pembahasan}

Dari paparan data penelitian di lapangan dapat memberi penjelasan bahwa masyarakat dayak memiliki sistem kemasyarakatan, organisasi sosial termasuk organisasi dayak tersendiri yang memiliki manfaat bagi masyarakat di desa mandomai.

1. Sistem kemasyarakatan suku dayak ngaju di desa mandomai

Bentuk kehidupan masyarakat dayak di desa mandomai pada awalnya adalah satu daerah sebagai tempat menetap bagi masyarakat desa sebelum adanya pemekaran wilayah desa mandomai. Termasuk juga perkawinan dalam masyarakat dayak desa mandomai yaitu perkawinan dengan sesama suku dan juga kehidupan setelah menikah dewasa ini kecendrungan terpisah dari keluarga kedua belah pihak. Dan untuk upacara adat dalam perkawinan ada namanya 17 barang adat seperti yang dikemukakan oleh lurah desa mandomai tetapi untuk acara adat yang lainnya di desa mandomai kurang kental karena banyaknya pendatang dari luar sehingga budaya Dayak di desa mandomai tersebut sedikit berkurang. Kemudian juga untuk memenuhi kebutuhan makan orang dayak dulu hingga sekarang adalah sebagai petani. Tetapi, seiring berjalan nya waktu dan zaman yang mulai maju masyarakat didesa mandomai sekarang berpindah porfesi ada yang menjadi Guru,pedagang dan pengusaha sawit. Untuk mata pencaharian nelayan di desa mandomai kurang bahkan tidak ada karena jumlah ikan yang ada di sungai desa mandomai cenderung sedikit sehingga banyaknya ikan yang dijual di desa mandomai itu berasal dari ekspor luar daerah.

2. Struktur organisasi sosial di suku Dayak ngaju desa mandomai Kalimantan tengah.

Organisasi sosial adalah wadah pengembangan generasi muda yang tumbuh dan berkembang atas dasar kesadaran dan tanggung jawab sosial dan untuk masyarakat terutama generasi muda diwilayah desa Mandomai, terutama untuk mengerakkan di bidang kesejahteraan sosial masyarakat. Organisasi sosial masyarakat dayak ngaju yang berada di desa mandomai memiliki struktur organisasi dan juga sangat memilki manfaat yang sangat besar bagi kehidupan masyarakat setempat, sepert organisasi pemuda karang taruna, ibu PKK, BPK, dll. kegiatan organisasi sosial di desa mandomai

a. Karang Taruna 
- Menumbuhkan kesadaran generasi muda akan tanggung jawab sosial

- Mengajarkan generasi muda bagaimana hidup bermasyarakat

- Membangun kerja sama antar masyarakat dalam suatu kegiatan

- Menumbuhkan potensi dalam diri setiap anggota

- Membantu masyarakat jika ada kegiatan desa

- Gototong royong

- Menyelenggarakan kegiatan pengembangan jiwa kewirausaaan bagi generasi muda dilingkungannya

- Penyelenggara usaha-usaha pencegahan permasalahan sosial yang aktual

- Menyelenggarakan pendidikan dan pelatihan bagi masyarakat

b. Ibu Pkk

- Dapat menggerakkan warga binaannya

- Memberikan penyuluhan kepada KK Binaanya

- Meningkatkan kesadaran hidup bergotong royong, kesetiakawanan sosial, keamanan lingkungan, Membangun Desa

- Mempererat tali silahturahmi dalam kegiatan ibu-ibu pkk

- Kegiatan tata boga antar ibu-ibu di desa
- Kegiatan membuat keterampilan dari rotan dll

- Kegiatan posyandu setiap tanggal 12

- Senam setiap pagi jum'at

- Pengajian atau ibadah mingguan

- Arisan ibu pkk

c. BPK Desa

- Pengawasaan saat mulai memasuki musim kemarau

- Membantu warga desa saat terjadinya kebakaran

- Membantu warga desa saat terjadinya bencana banjir

- Membantu warga desa dalam gotong royong membersihkan desa

d. FOR Dayak

- Menggatang utus uluh Dayak

- Menerapkan falsafah huma betang

- Pancasila sebagai ideologi

- Membantu penyelenggaraan kegiatan ritual adat

- Penyelenggara pelatihan dan pemberdayaan masyarakat desa

- Pawai budaya

- Pameran busana dayak

- Kuliner dayak

- Permainan tradisional

- Lomba menyanyi karungut

- Tarian khas dayak

3. Struktur organisasi desa mandomai

a. Struktur organisasi pemerintah keluarahan mandomai

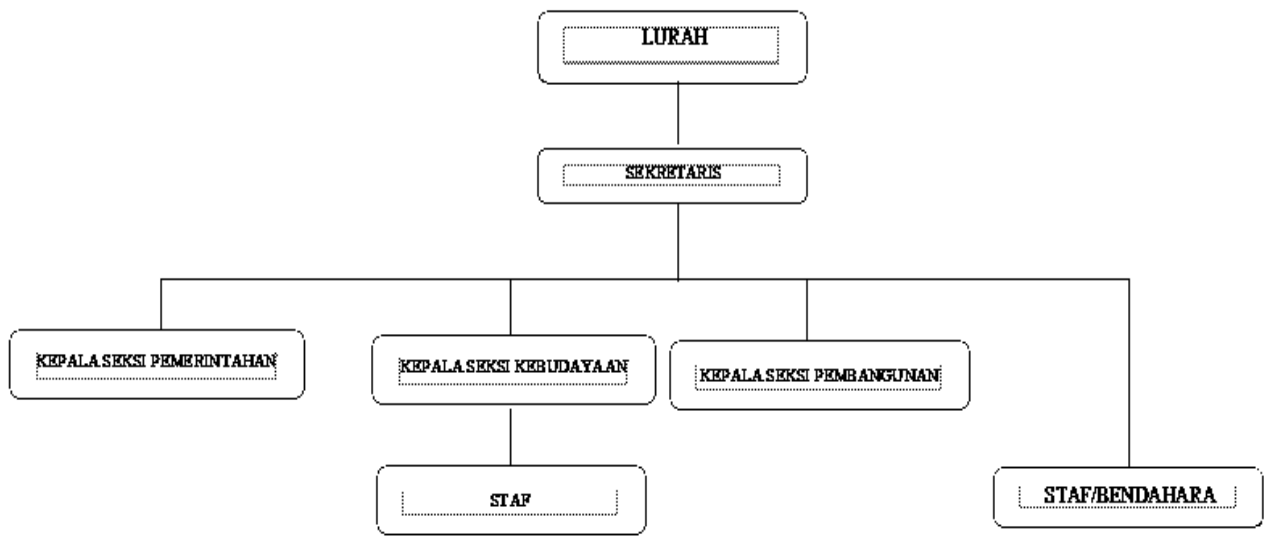


b. Struktur organisasi karang taruna desa mandomai

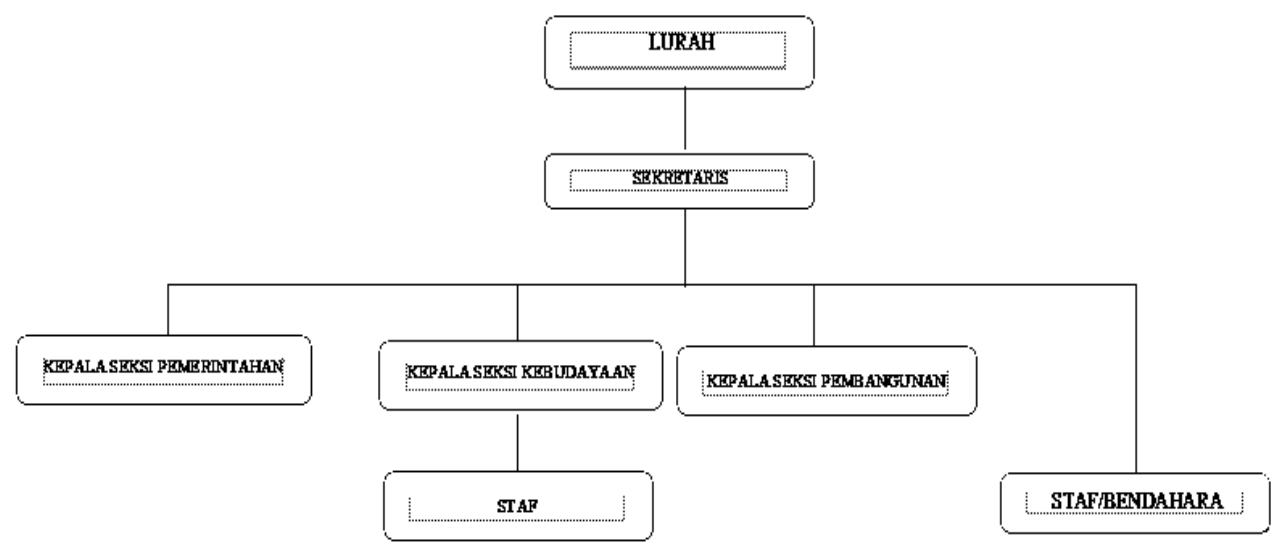

c. struktur organisasi ibu Pkk desa mandomai

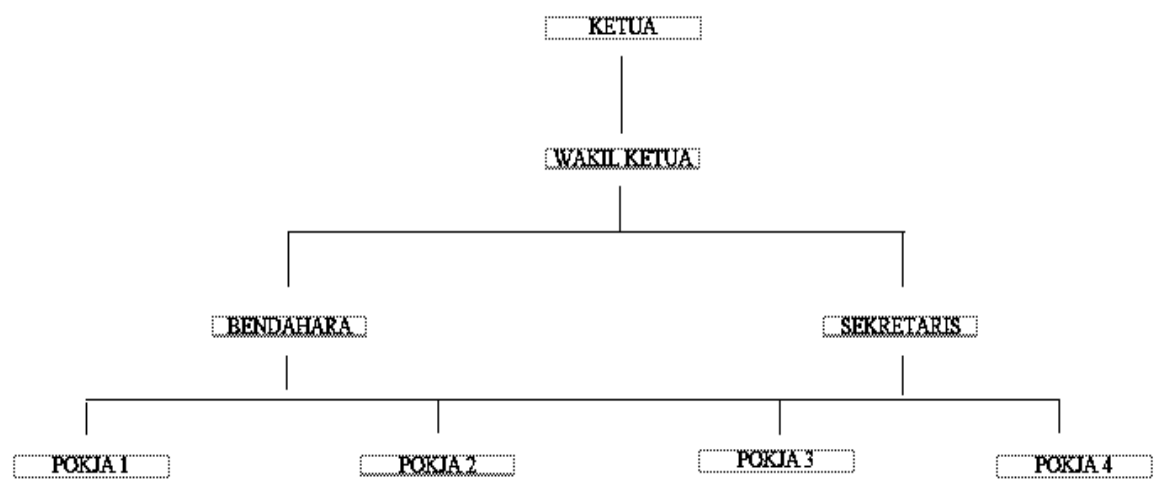

d. struktur organisasi BPK desa mandomai

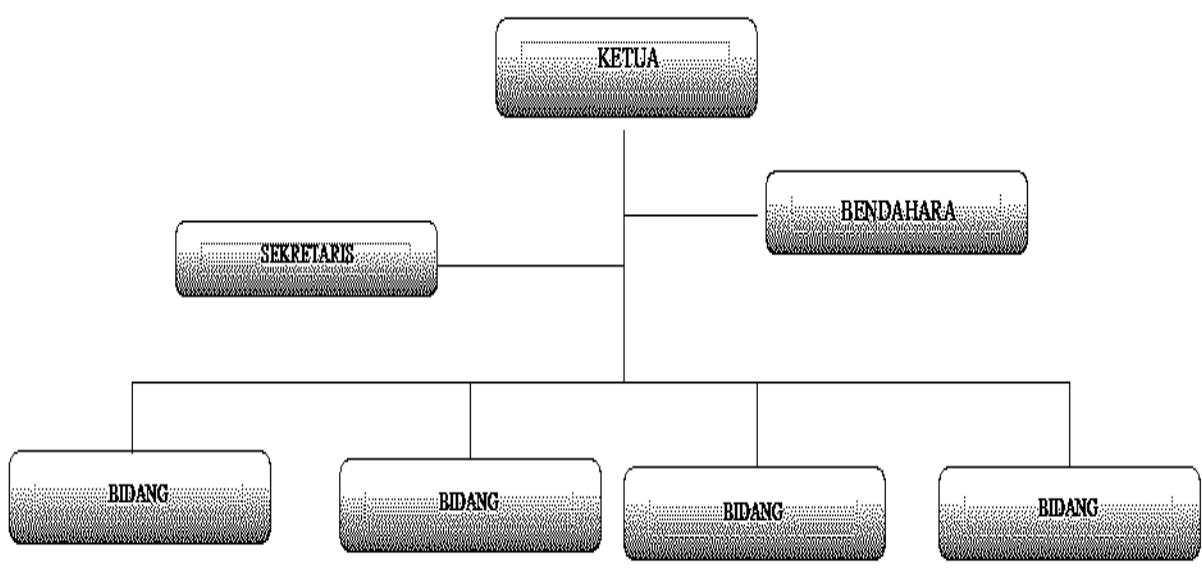


e. Struktur organisasi FOR DAYAK desa mandomai

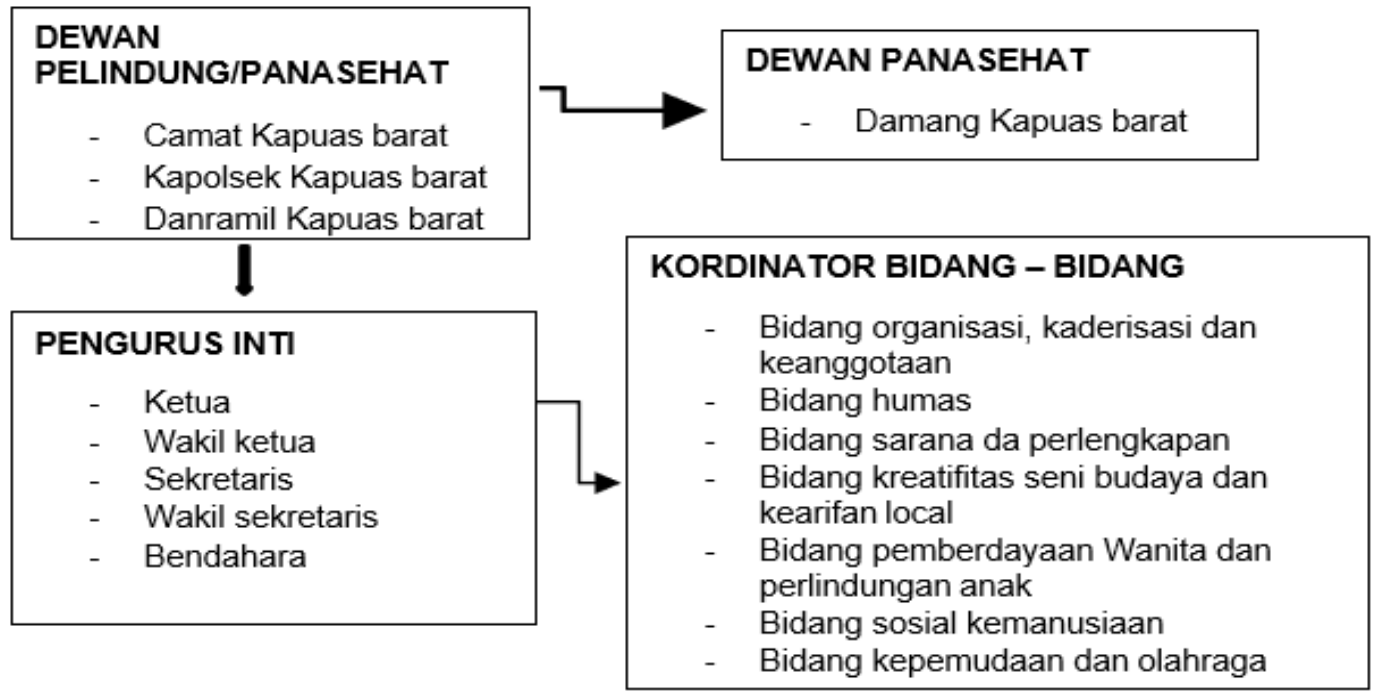

4. Dinamika perubahan struktur organisasi sosial suku Dayak ngaju didesa mandomai Kalimantan tengah.

Dapat diketahui bahwa ada pergeseran kegiatan sosial masyarakat dayak di desa mandomai yang dulunya tidak ada kegiatan sosial antar sesama masyarakat, kini sudah menjadi rutinitas masyarakat dalam menjalankan kehidupannya baik dalam kesehatan, juga keamanan masyarakat setempat (Nurgiansah, 2019).

Kemudian organisasi sosial suku dayak ngaju di desa mandomai banyak mengalami perubahan keanggotaan setiap kali periode masa jabatan kepala desa hingga menjadi lurah, artinya setiap kali perubahan kepala desa maka waktu itu pula struktur keanggotaan organisasi sosialnya juga berubah, karena mengikuti arahan oleh kepala desanya hingga menjadi lurah seperti saat ini. Sehingga organisasi di desa mandomai juga setiap periode nya berubah sesuai dengan kebijakan Lurahnya.

Adapun yang di maksud Perubahan keanggotaan dalam organisasi sosial di desa mandomai agar tindakan beralihnya suatu organisasi saat ini menuju kondisi masa yang akan datang yang di inginkan guna meningkatkan efektivitas dan efesiensi organisasi, suatu organisasi perlu melakukan perubahan dalam kegiatannya karena lingkungan organisasi secara terus menerus mempunyai perubahan sehingga organisasi perlu melakukan perubahan keanggotaan sesuai dengan pemimpin yang menjabat sebagai lurah mandomai saat ini agar tetap searah pemikiran seorang pemimpin dan anggota-anggota organisasi sosial dalam apa yang sudah di rencanakan atau di cita-cita kan sebuah kesejahteraan desa dan pula agar tetap eksis dan sukses di masa mendatang. Karena jika tidak ada perubahan keanggotaan dalam organisasi tidak akan berjalan ke arah yang di citacitakan apabila para pemimpinnya dan anggotanya tidak ada perubahan sehingga sebuah organisasi tidak bisa tumbuh dan berkembanng sebab karakteristik setiap individu yang berbeda-beda dan cara pandang dalam pemikiran tidak sama pula dari sisi itulah menimbulkan sebuah terjadinya perubahan anggota organisasi sosial tersebut.

\section{KESIMPULAN}

Sistem kekerabatan yang dianut oleh suku bangsa Dayak adalah bilateral, yaitu menarik garis keturunan melalui pihak 
ayah dan ibu. Dengan demikian sistem pewarisanpun tidak membedakan anak laki-laki dan anak perempuan. Bentuk kehidupan keluarga terdiri atas dua jenis yaitu keluarga batih (nuclear family) dan keluarga luas (extended family). Pada kedua bentuk keluarga ini biasanya terdapat wali/asbah yang berfungsi untuk mewakili keluarga dalam berbagai kegiatan sosial dan politik di lingkungan dan di luar keluarga. Yang menjadi wali/asbah dalam keluarga batih adalah anak laki-laki tertua, sedangkan dalam keluarga luas yang berhak menjadi wali/asbah adalah saudara laki-laki ibu dan saudara laki-laki ayah. Misalnya dalam hal pernikahan, maka orang yang paling sibuk mengurus masalah ini sejak awal hingga acara selesai adalah para wali/asbah. Dengan demikian semua permasalahan dan keputusan keluarga harus dikonsultasikan dengan wali/asbah. Penunjukan wali/asbah biasanya dilakukan berdasarkan kesepakatan keluarga dan bukan melalui pemilihan.

Hasil penelitian ini masih dapat dikembangkan, terutama dalam menjaga kebudayaan leluhur Dayak desa mandomai dikaitkan dengan system kemasyarakatan dan organisasi Dayak ngaju di desa mandomai. Sehingga diharapkan mampu memberikan informasi kepada masyarakat umum seperti apa masyarakat desa mandomai dalam menjalankan dan menjaga budayanya walaupun banyak pengaruh yang dating dari luar.

Dalam penelitian ini masih ada kekurangan, baik dalam mengumpulkan data maupun dalam mengelola sampai menyajikan data. Peneliti menyadari masih banyak kekurangan dalam penelitian ini, maka peneliti menerima saran yang dapat membangun demi memperbaiki penelitianpenelitian dan penulisan selanjutnya.

\section{DAFTAR PUSTAKA}

Darmadi, Hamid, Jurnal Pendidikan Sosial Vol.3 No. 2 Desember 2016, Dayak Asal Usul dan Penyebarannya di Bumi Borneo. Pontianak

Dewantara, J. A., \& Nurgiansah, T. H. (2021). Building Tolerance Attitudes Of PPKN Students Through Multicultural Education Courses. Jurnal Etika Demokrasi, 6(1), 103-115.

Eviyanti, S. (2010). Taman Budaya Kalimantan Tengah. Yogyakarta: Universitas Atma Jaya Yogyakarta.

Meleong, L. J. (2013). Metode Penelitian Kualitatif . Bandung: PT. Remaja Rosadakarya. (2005). Metodologi penelitian kualitatif. Bandung

Norliansyah. (2010). sejarah singkat mandomai. informasi kapuas.

Nurgiansah, T. H. (2019). Pemutakhiran Kurikulum Pendidikan Kewarganegaraan di Era

Revolusi Industri 4.0. Prosiding Seminar Kewarganegaraan Universitas Negeri Medan, 1(1), 95-102.

Nurgiansah, T. H. (2020). Filsafat Pendidikan. In Banyumas: CV Pena Persada.

Nurgiansah, T. H. (2021a). Partisipasi Politik Masyarakat Sleman di Masa Pandemi Covid-19 dalam Konteks Pendidikan Kewarganegaraan. Jurnal Civic Hukum, 6(1), 1-9.

Nurgiansah, T. H. (2021b). Pendidikan Pancasila. In Solok: CV Mitra Cendekia Media.

Nurgiansah, T. H. (2021c). Petuah Pendidikan Kewarganegaraan Dalam Kontestasi Politik. AoEJ: Academy of Education Journal, 12(1), 39-47.

Nurgiansah, T. H. (2021d). The Role of Citizenship Education in Building Bantul Community Political Participation in The Pandemic Covid 19. Prosiding Seminar Nasional Pendidikan Dan Kewirausahaan, 4(1), 1-4.

Pitoyo \& Triwahyudi. 2017. Dinamika perkembangan etnis di Indonesia dalam konteks persatuan Negara. Jurnal Populasi, No.1. hal.71 
Riwut, t. (2007). kalimantan membangun alam dan kebudayaan cetakan ke dua. yogyakarta: NR Publishing.

Riswanto Dody, d. (2017) Kompetensi multikultural konselor pada kebudayaan suku dayak kaliamntan tengah, JOMSIGN : Jurnal of Multicurtural Studies in Guidance and Counseling,217.

Sugiyono, P. D. (2018). Metode Penelitian Kualitatif. Bandung: Alfabeta.

Sukmadinata, N. S. (2013). Metode Penelitian Pendidikan. Bandung: PT. Remaja Rosdakarya.

Widen, K., \& Johansen, P. (2009). organisasi sosial lokal suku bangsa dayak ngaju di kalimantan tengah. Jakarta. 